\title{
Structure, phase composition and mechanical properties in bioinert zirconium-based alloy after severe plastic deformation
}

\author{
A. Yu. Eroshenko', A. M. Mairambekova ${ }^{1,2}$, Yu. P. Sharkeev ${ }^{1,3}$, Zh. G. Kovalevskaya ${ }^{1,3, \dagger}$, \\ M. A. Khimich ${ }^{1,2}$, P. V. Uvarkin ${ }^{1}$ \\ †kovalevskaya@ispms.tsc.ru \\ ${ }^{1}$ Institute of Strength Physics and Materials Sciences, SB RAS, pr. Akademicheskii, 2/4, Tomsk, 634055, Russia \\ ${ }^{2}$ National Research Tomsk State University, Lenin ave., 36, Tomsk, 634050, Russia \\ ${ }^{3}$ National Research Tomsk Polytechnic University, Lenin ave., 30, Tomsk, 634050, Russia
}

Bioinert $\mathrm{Zr}-1 \mathrm{Nb}$ alloy, which is a prospective material for the fabrication of implants for different applications, is studied. Annealed billets of the alloys are subjected to severe plastic deformation including multi-cycle abc-pressing and multipass rolling in grooved rolls. The abc-pressing stage involves three cycles of pressing within the temperature range $500-400^{\circ} \mathrm{C}$ with one pressing in each cycle at a given temperature. In the second stage, the billets are deformed through rolling in grooved rolls at room temperature. Rolling in grooved rolls provided the formation of a homogeneous structure throughout the bulk billet volume and additional grain refinement. After annealing the alloy had a fine-grained structure consisting of $2.8 \mu \mathrm{m}$ sized equiaxial $\alpha-\mathrm{Zr}$ matrix grains and $0.4 \mu \mathrm{m}$ sized $\beta$-Nb particles distributed on the boundaries and interiors of $\alpha$ - $\mathrm{Zr}$ matrix grains. As a result of severe plastic deformation, a binary ultrafine-grained alloy with $0.2 \mu \mathrm{m}$ size of structural elements was obtained. Transmission electron microscopy shows that the microstructure of the alloy consists of $\alpha$-Zr grains, while $\beta$-Nb phase grains are not identified structurally or via X-ray diffraction. Only the diffraction identification analysis reveals the presence of $\beta$-Nb in the alloy. Ultrafine-grained structure enhances the mechanical properties of the alloys: yield stress $450 \mathrm{MPa}$, ultimate tensile strength $780 \mathrm{MPa}$, and microhardness $2800 \mathrm{MPa}$ are obtained while keeping a low value of Young's modulus (51 MPa) comparable to the Young's modulus of bone tissue.

Keywords: Zr-1Nb alloy, severe plastic deformation, ultrafine-grained structure, Young's modulus.

\section{Introduction}

Valve bioinert metals such as titanium, zirconium, niobium, and their alloys are successfully used in medicine [1]. Pure titanium and titanium alloys find a particularly wide application in this field [2-5]. Young's modulus of titanium ranges from 100 to $120 \mathrm{GPa}$ that is significantly higher than the Young's modulus of bone tissue, which ranges from 5 to $50 \mathrm{GPa}$ [2]. A low Young's modulus would allow a uniform distribution of strain and stress at the «bone-implant» interfaces and thus exclude the possible failure of bone at the places of rigid fixation of the implant to the bone and bone resorption in areas of zero mechanical loading. In view of this fact, bioinert titanium $\beta$-alloys such as $\mathrm{Ti}-\mathrm{Nb}$ and $\mathrm{Ti}-\mathrm{Nb}-\mathrm{Zr}$ are of interest for using as implant materials [3-7], for these alloys have low Young's modulus close to that of bone tissue. In recent years, it has become possible to use also zirconium-based alloys in the medicine [1, 8-10]. Like titanium alloys, they have a high corrosion resistance, fatigue strength and bioinertness [11]. At present, medical implants and tools are made of niobium doped zirconium [8-10]. Alloys of the zirconium-niobium system belong to the group of alloys with solid-solution hardening and have no tendency to magnetization. Niobium alloyed zirconium possesses a high fatigue strength, which weakly depends on its structure [11]. According to literature references, Young's modulus of zirconium and zirconium-niobium system alloys ranges within 58-99 GPa depending on the initial structural and phase state and the content [12-14]. It should be noted that a comparison of the existing experimental data on the Young's modulus is difficult due to different techniques of its measurements used [13-14].

Mechanical properties of zirconium-based alloys are not sufficiently high for their possible application in the medicine. An efficient control of the microstructure and strength of the alloys is possible by the use of different thermo-mechanical and deformation processing methods, for example, by furthers the formation of nanostructured or ultrafine-grained structure by severe plastic deformation (SPD) [15-19].

It is known that the formation of nanostructured and ultrafine-grained structures in bioinert alloys by SPD methods produces billets and products with significantly higher mechanical properties. Therefore, the studies on the development of new ultrafine-grained materials for medical applications are of a great current interest. In the present paper, experiment results on the structural and phase state and mechanical properties of bioinert binary $\mathrm{Zr}-1 \mathrm{Nb}$ alloy after SPD are described. 


\section{Methodology}

The material for study was the $\mathrm{Zr}-1 \mathrm{Nb}$ alloy, chemical composition of which is presented in Table 1.

Table 1. Chemical composition of Zr-1Nb alloy.

\begin{tabular}{|c|c|c|c|c|c|}
\hline \multicolumn{7}{|c|}{ Element concentration, wt. \% } \\
\hline $\mathrm{Zr}$ & $\mathrm{Nb}$ & $\mathrm{Mo}$ & $\mathrm{W}$ & $\mathrm{Fe}$ & $\mathrm{Ti}$ \\
\hline 96,54 & 1,01 & $\leq 0,32$ & $\leq 0,1$ & $\leq 0,29$ & $\leq 0,88$ \\
\hline
\end{tabular}

The as-received material had the shape of a commercial bar. Prior to deformation, the samples were annealed in vacuum for 3 hours at $580^{\circ} \mathrm{C}$.

The ultrafine-grained structure in the alloy under study was processed using a combined two-stage SPD method, which included abc-pressing followed by multipass rolling with grooved rolls [19]. During the first stage, samples were deformed by abc-pressing, which consisted of three cycles of upsetting in the temperature interval of $500-400^{\circ} \mathrm{C}$. When passing from one pressing cycle to the next one, the temperature of the samples was reduced step by step in the temperature interval indicated. In the second stage the billets were deformed by rolling in grooved rolls to the strain of $75 \%$ at room temperature. Rolling in grooved rolls resulted in the formation of a homogeneous structure throughout the bulk billet volume and an additional grain refinement. After rolling square bars with the sizes $(6 \times 6 \times 400) \mathrm{mm}^{3}$ were produced. To reduce internal stresses and increase the ductility, the bars produced were annealed for 1 hour at $350^{\circ} \mathrm{C}$ in argon atmosphere. The changes of the structural and phase state and mechanical properties as a result of SPD were studied then.

Microstructure and phase composition were characterized by optical microscopy (Carl Zeiss Axio Observer), transmission electron microscopy (JEOL JEM 2100 microscope) and X-ray diffraction analysis (ADVANCE D8 Bruker diffractometer). X-ray diffraction patterns were obtained in $\mathrm{CuK}_{\alpha}$-radiation. The average sizes of structure elements (grains, subgrains, fragments) were calculated by the intercept methoid to ASTM E1382-97 (2010) standard [20]. Vickers microhardness was measured using microhardness tester Duramin 5. The mechanical properties, such as yield stress, ultimate tensile strength, ductility, were evaluated by tensile tests. The tests were conducted on a universal testing machine Walter+Bay LFM-125 at room temperature. The dogbone tensile specimens were flat with dimensions of gage section of $(40 \times 4) \mathrm{mm}^{2}$ and the thickness of $1.5 \mathrm{~mm}$. The strain rate was $3 \times 10^{-3} \mathrm{~s}^{-1}$. Young's modulus was determined by Nano Hardness Tester during the hardness indentation on a sample surface with simultaneous plotting of load-unload kinetic diagrams. Graphical differentiation of the unloading curve allowed determining the Young's modulus of samples under study [21].

\section{Results and discussion}

After annealing the microstructure of the alloy consisted of $2.8 \mu \mathrm{m} \alpha-\mathrm{Zr}$ equiaxial matrix grains and $0.4 \mu \mathrm{m} \beta-\mathrm{Nb}$ particles distributed on the boundaries and interiors of $\alpha-\mathrm{Zr}$ matrix grains (Fig. 1a,b). According to the classification presented in [22], the matrix grain size corresponds to the fine-grained structure.

The selected area diffraction (SAD) pattern revealed the reflections of two phases, $\alpha-\mathrm{Zr}$ (HCP lattice) and $\beta-\mathrm{Nb}$ (BCC lattice). $\alpha$-Zr reflections have a high intensity, while the $\beta$-Nb reflexes a low intensity (Fig. 1c) that indicates on a small volume fraction of niobium.

The microhardness distribution was shown to be uniform and the average microhardness value of zirconium alloy in the recrystallized state was $1540 \mathrm{MPa}$ and the Young's modulus was equal to $59 \mathrm{GPa}$.

As a result of the two-stage deformation processing (abcpressing with rolling) ultrafine-grained state was formed throughout the bulk billet volume. The microstructure of the alloy in this $\mathrm{Zr}-1 \mathrm{Nb}$ alloy microstructure is represented in Fig. 2a, b.

The figures show that the microstructure consists of grains and subgrains. The bright-field images of the microstructure contain many extinction contours, which are mostly localized at subgrain and fragment boundaries (in Fig. 2a, they are shown by arrows). The presence of blurred boundaries and extinction contours indicates on a level of high internal stresses. Point reflects on microdiffraction pattern are arranged along circles with a typical azumuthal spreading indicating that both high-angle grain boundaries and small-angle subgrain and grain boundaries exist (Fig. 2a, insert). The microdiffraction pattern revealed reflections of high intensity $\alpha-\mathrm{Zr}$ phase and low intensity $\beta-\mathrm{Nb}$ phase.

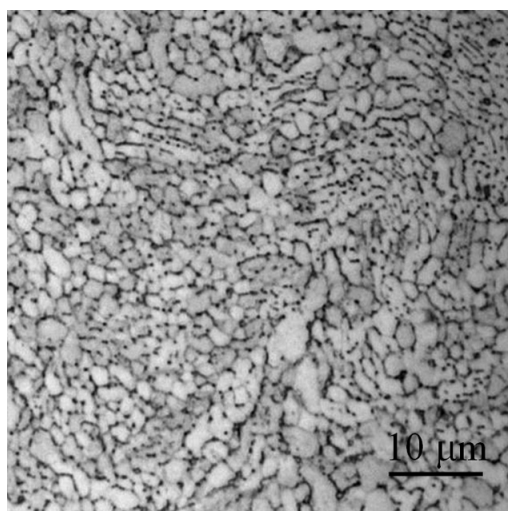

a

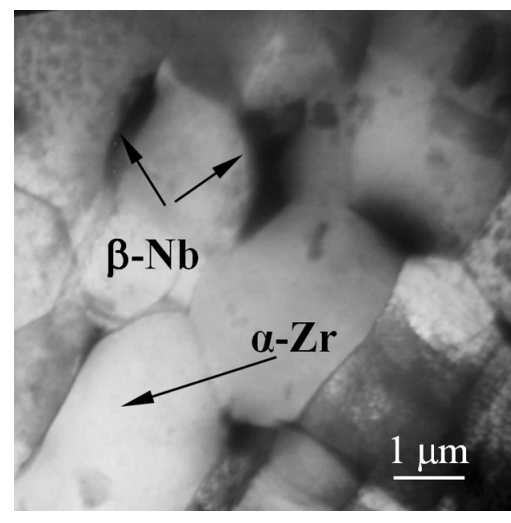

$\mathrm{b}$

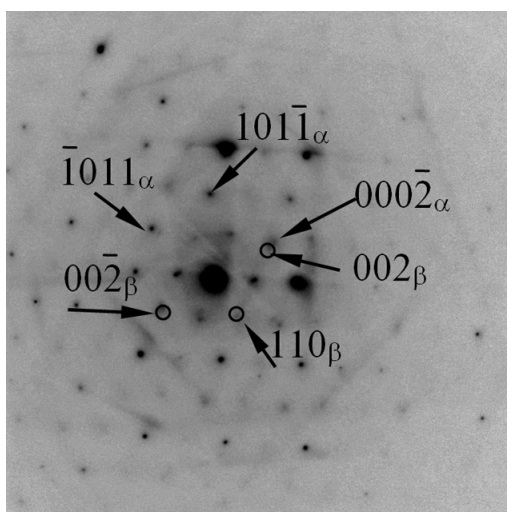

c

Fig. 1. Optical (a) and bright-field TEM images (b) with corresponding SAD-pattern (c) of Zr-1Nb alloy in annealed state. 
It should be noted that niobium phase was not distinctly observed on light-field images.

An estimate of the average size of structural elements, i.e. as grains, subgrains and fragments, yields the value of about $0.22 \mu \mathrm{m}$. From the histogram of size distribution of structural elements (Fig. 2c) it follows that the elements with sizes below $0.2 \mu \mathrm{m}$ occupy about $40 \%$ of the volume, those with sizes in interval $0.2-0.4 \mu \mathrm{m}$ about $55 \%$, and the elements with sizes above $0.4 \mu \mathrm{m}$ approximately $5 \%$ of the volume.

X-ray diffraction patterns of the samples of alloy in the initial fine-grained state and after SPD are presented in Fig. 3a, b.

The main $\alpha-\mathrm{Zr}$ phase reflexes are presented in X-ray diffraction patterns of both the fine-grained and ultrafinegrained states. The $\beta-\mathrm{Nb}$ phase reflexes, which were identified on electron microscopy microdiffraction patterns, are not observed by X-ray diffraction method.

Young's modulus value of ultrafine-grained zirconium alloy has been found to be equal to $51 \mathrm{GPa}$ that is comparable to the Young's modulus of bone tissue.

Presented in Table 2 are the mechanical characteristics of several medical alloys and $\mathrm{Zr}-1 \mathrm{Nb}$ alloy in different structural states. Here, $\sigma_{0.2}$ is the yield stress, $\sigma_{\mathrm{B}}$ is the ultimate tensile strength, $\delta$ is the elongation to failure, $H \mu$ is the microhardness, and $E$ is the Young's modulus. From this table, one can see that ultrafine-grained zirconium possesses strength characteristics much higher than those of the fine grained alloy and comparable with the strength properties of widely used titanium alloys simultaneously with a reasonable ductility. At the same time, zirconium alloy has a significantly lower Young's modulus than commercially pure titanium Grade 4 and consists of only bioinert metallic elements, which are non-toxic for human organism.

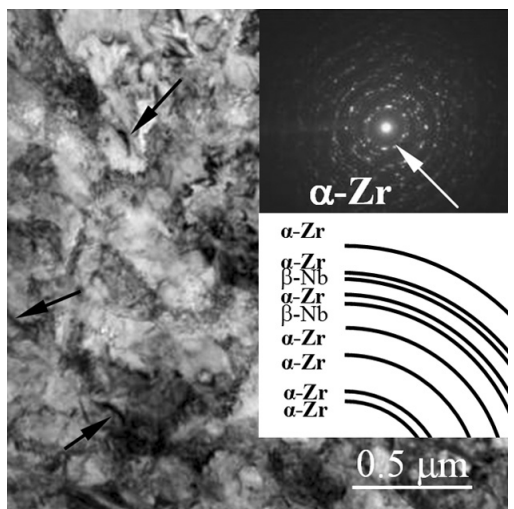

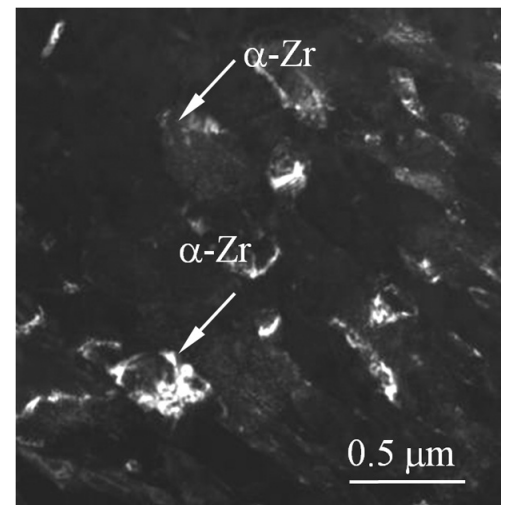

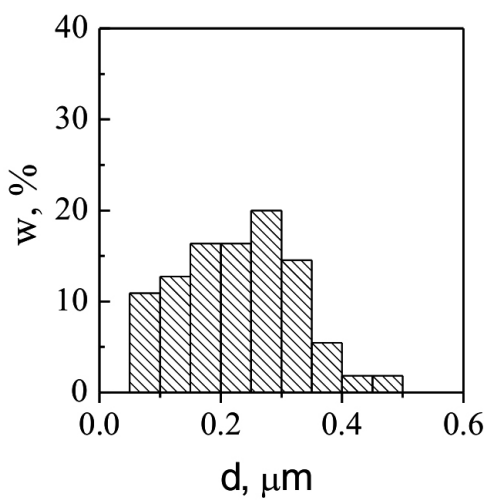

Fig. 2. Bright-field TEM image with a corresponding SAD-pattern (a), dark-field image (b), and histogram of structural elements' size distribution (c) of ultrafine-grained $\mathrm{Zr}$-1 $\mathrm{Nb}$ alloy.

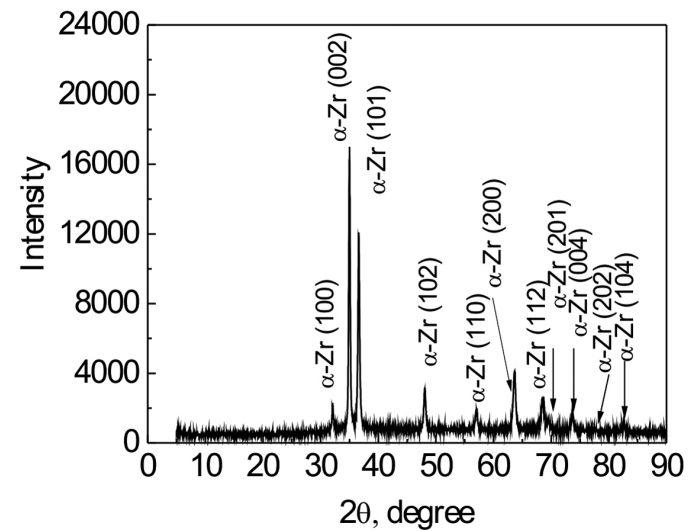

a

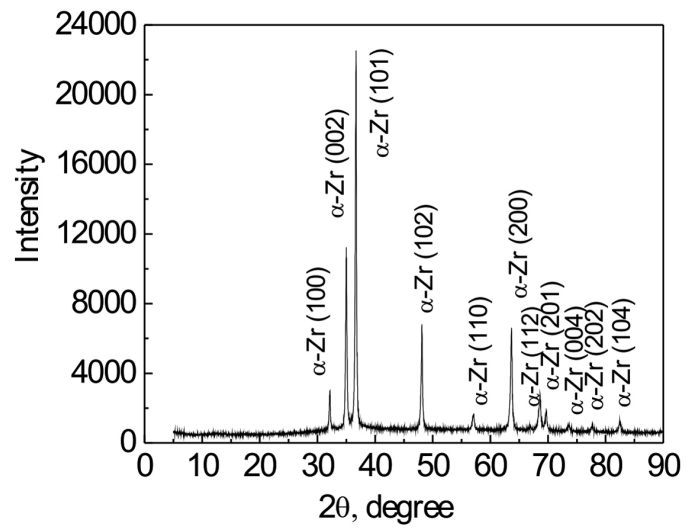

Fig. 3. X-ray diffraction patterns of Zr-1Nb alloy in different structural states: initial fine-grained state (a); ultrafine-grained state (b).

Table 2. Mechanical properties of Zr-1Nb alloy, unalloyed iodide zirconium and Grade 4 [23-25].

\begin{tabular}{|c|c|c|c|c|c|}
\hline Material & $\sigma_{0.2}, \mathrm{MPa}$ & $\sigma_{\mathrm{B}}, \mathrm{MPa}$ & $\delta, \%$ & $H \mu, \mathrm{MPa}$ & $E, \mathrm{GPa}$ \\
\hline Grade 4 & $\geq 480$ & $\geq 550$ & 15 & 2200 & 114 \\
\hline Iodide zirconium $^{*}$ Zr-1Nb alloy, fine-grained & 80 & 220 & 45 & 1500 & 100 \\
\hline Zr-1Nb alloy, ultrafine-grained & 200 & 430 & 14 & 1540 & 59 \\
\hline & 450 & 780 & 7 & 2800 & 51 \\
\hline
\end{tabular}

${ }^{*}$ Results of the investigations presented in this paper 


\section{Conclusion}

Thus, using a combination of SPD by multiple abc-pressing followed by multi-pass rolling an ultrafine-grained structure has been formed in binary $\mathrm{Zr}-1 \mathrm{Nb}$ alloy. The average size of structural elements of the alloy after this treatment was as small as about $0.2 \mu \mathrm{m}$. The ultrafine-grained structure formed consisted mainly of $\alpha$-Zr grains. Structurally, $\beta-\mathrm{Nb}$ grains have not been identified. Existence of $\beta$-Nb phase has been proved only by the diffraction analysis. The ultrafinegrained structure gave the alloy a high level of mechanical properties (yield stress about $450 \mathrm{MPa}$, ultimate tensile strength $780 \mathrm{MPa}$, and microhardness $2800 \mathrm{MPa}$ ) at low Young's modulus of $51 \mathrm{GPa}$. The bioinert binary $\mathrm{Zr}-1 \mathrm{Nb}$ alloy with an ultrafine-grained structure having low Young's modulus and high mechanical characteristics can be a prospective material for the fabrication of implants for various applications.

Acknowledgments. This study was conducted in accordance with project III.23.2.2 of the Program of Fundamental Researches of SB RAS, State Assignment of ISPMS SB RAS 2017-2019.

\section{References}

1. Titanium, niobium, zirconium and tantalum for medical and surgical applications. Book edited by L. D. Zardiackas, M.J. Kraay, H.L. Freese. ASTM International. (2006) $265 \mathrm{p}$.

2. M. Abdel-Hady Gepreel, M. Niinomi. J. Mechan. Behav. Biomed. Mater. 20, 407 (2013). DOI: 10.1016/j. jmbbm.2012.11.014.

3. R. Banerjee, S. Nag, H. L. Fraser. Mater. Sci. Eng. C 25, 282 (2005). DOI: 10.1016/j.msec.2004.12.010.

4. M.T. Mohammed, Z.A. Khan, A. N Siddiquee. Int. J. Chem. Mol. Nucl. Mater. Metall. Eng. 8, 788 (2014).

5. Zh.G. Kovalevskaya, M. A. Khimich, A.V. Belyakov, I. A. Shulepov. Adv. Mater. Res. Sci. J. 1040, 39 (2014). DOI: 10.4028/www.scientific.net/AMR.1040.39.

6. Yu. P. Sharkeev, A. Yu. Eroshenko, Zh. G. Kovalevskaya, A. A Saprykin, E. A. Ibragimov, I.A. Glukhov, M. A. Khimich, P.V. Uvarkin, E. V. Babakova. Russian Phys. J. 59, 430 (2016).

7. M.B. Sedelnikova, Yu.P. Sharkeev, E.G. Komarova, I.A. Khlusov, V.V. Chebodaeva. Surf. Coat. Technol. 307PC, 1274 (2016). DOI: 10.1016/j.surfcoat.2016.08.062.

8. M.S. Ivanova, M.A. Pirozhkova. Russian Dental J. 3, 40-44 (2008). (in Russian) [M.С. Иванова, М.А. Пирожкова. Российский стоматологический журнал. 3, 40 - 44 (2008)]

9. C. Nobert, H. Dena, M. Andrea. Periodontol 2000. 73, 241 (2017). DOI: 10.1111/prd.12180.

10. M.B. Sedelnikova, E.G. Komarova, Yu. P. Sharkeev, T.V. Tolkacheva, I. A. Khlusov, L.S. Litvinova, K. A. Yurova, V.V. Shupletsova. Bioactive Mater. 2, 177 (2017). DOI: 10.1016/j.bioactmat.2017.01.002.
11. Corrosion and Corrosion Protection. Handbook edited by P. A. Schweitzer. New York, Marcel Dekker. Inc. (1989) $660 \mathrm{p}$.

12. M. A. Filyand, E.I. Semenova. Properties of rare elements. Handbook. Moscow, Metallurgy. (1964) 913 p. (in Russian) [M. А. Филянд, Е.И. Семенова. Свойства редких элементов. Справочное пособие. Москва, Металлургия. (1964) 913 С.]

13. G.L. Millar. Zirconium. Book. London, Butterworth Scientific Publications. (1954) 239 p.

14. R. Kondo, N. Nomura, Suyalatu, Y. Tsutsumi, H. Doi, T. Hanawa. Acta Biomaterialia. 7, 4278 (2011). DOI: 10.1016/j.actbio.2011.07.020.

15. R.Z. Valiev, A.P. Zhilyaev, T.G. Langdon. Bulk nanostructured materials: fundamentals and applications. Book. New Jersey, John Wiley, Hoboken, New Jersey, USA, and TMS. (2014) $456 \mathrm{p}$.

16. G.P. Grabovetskaya, I.P. Mishin, E.N. Stepanova, I. P. Chernov, D. Yu. Bulynko. Steel in Translation. 45 (2), 111 (2015).

17. L.Y. Egorova, Y.V. Khlebnikova, V.P. Pilyugin. Letters on Materials. 6 (3), 237-242 (2016). (in Russian) [Л. Ю. Егорова, Ю.В. Хлебникова, В.П. Пилюгин. Письма о материалах. 6 (3), 237-242 (2016)] DOI: 10.22226/2410-3535-2016-3-237-242

18. Yu.P. Sharkeev, Zh.G. Kovalevskaya, M.A. Khimich, V.A. Bataev, Q. Zhu, A.V. Belyakov, I.A. Gluhov. Key Eng. Mater.: Sci. J. 683, 174 (2016). Doi:10.4028/ www.scientific.net/KEM.683.174.

19. Y.P. Sharkeev, A.Y. Eroshenko, K.S. Kulyashova, K. A. Suvorov, S.V. Fortuna, M. Epple, O. Prymak, V. Sokolova, S. Chernousova. Materialwissenschaft und Werkstofftechnik. 44 (2-3), 198 (2013). DOI: 10.1002/ mawe.201300113.

20. ASTM E1382-97 (2010) Standard Test Methods for Determining Average Grain Size Using Semiautomatic and Automatic Image Analysis.

21. H.-Keun Park, Y.K. Hong, S. Q Lee, S. Kee. Materials of the SPIE International Conference on Opto-mechatronic Actuators, Sensors and Control. SPIE, Philadelphia. 5602 (2004) p. $115-121$.

22. E. V. Kozlov, N. A. Koneva, L. I. Trishkina, A. N. Zhdanov. Russ. Metall. 4, 264 (2010).

23. A.S. Zaymovskii, A.V. Nikulina, A.G. Reshetnikov. Zirconium alloys in nuclear engineering. Book. Moscow, Energoatomizdat. (1994) 253 p. (in Russian) [А.С. Займовский, А. В. Никулина, Н. Г. Решетников. Циркониевые сплавы в ядерной энергетике. Книга. Москва, Энергоатомиздат. (1994) 253 С.]

24. A.-H. Gepreel, M. Niinomi. J. Mech. Behav. Biomed. Mat. 20, 407 (2013).

25. V.L. Praskevich. Dental Implantology: Foundations of theory and practice. Handbook. Minsk, "Unipress". (2002) 268 p. (in Russian) [В. Л. Праскевич. Дентальная имплантология: Основы теории и практики. Справочное пособие. Минск, «Юнипресс». (2002) 268 c.] 